\title{
Klasik Türk şiirindeki vefa kavramının Mahmûd Nedîm Paşa Divanı'nda tezahürü
}

\section{Niyazi ADIGÜZEL ${ }^{1}$}

\begin{abstract}
APA: Adıgüzel, N. (2019). Klasik Türk şiirindeki vefa kavramının Mahmûd Nedîm Paşa Divanı'nda tezahürü. RumeliDE Dil ve Edebiyat Araşttrmaları Dergisi, (17), 191-205. DOI: 10.29000/rumelide.656691
\end{abstract}

$\ddot{\mathbf{O} z}$

Vefa duygusu; sevgi, saygı, dürüstlük, hoşgörü ve alçakgönüllülük gibi insanî değerlerin başında gelir ve bütün bu değerlerin anahtarı mesabesindedir. Bu duygu sanatkârlar elinde özellikle de şairlerce yüzyıllar boyunca genelde olumsuz yanıyla yani vefasızlık olarak ele alınmıştır. Klasik Türk şiirinde hemen hemen tüm şairler vefasızlıktan yakınmışlardır. Gerek sevgiliden gerekse felek ya da devrin kadirbilmezliğinden şikâyet babında, şairler vefa kavramını sıklıkla kullanmışlardır. Bu kavram çoğunlukla, âşık maşuk/sevgili ilişkisi bağlamında değerlendirilmiştir. Bu bağlamda ele alınan sevgili genelde vefasız; âşık ise tam manasıyla vefa abidesidir. Vefa kavramına en çok yer veren şairlerden biri de Mahmud Nedim Paşa'dır. O, yüzyıllardır süregelen klasik Türk şiiri geleneğinde vefa kelimesini redif olarak kullanan nadir şairlerdendir. Onun divanında pek çok beyitte karşılaştığımız vefa kavramının iki gazelinde redif ve iki musammatında da nakarat olarak kullanılması şairin siyasi kimliği ve hayatı ile yaşadığı dönem hakkında önemli ipuçları elde edeceğimizi düşündürmektedir. Vefa kavramını birçok beytinde ve aynı zamanda redif ve nakarat olarak şiirlerinde kullanmış olması bu kavramı işlerken klasik Türk şiirinde neden bu şairi seçtiğimizin cevabını da vermektedir.

Anahtar kelimeler: Klasik Türk edebiyatı, vefa, âşık-maşuk, Mahmûd Nedîm Paşa.

\section{Reflections of the term 'loyalty' in classical Turkish poetry, in Mahmud Nedim Pasha's Diwan}

\begin{abstract}
The sense of loyalty is at the forefront of human values such as love, respect, honesty, tolerance and humility and might stand as a key to all these values. This feeling has been studied by various artists for centuries, especially by poets, with its negative side; disloyalty. In classical Turkish poetry, almost all poets in their works complained of disloyalty. Poets have frequently used the concept of loyalty either to make a complaint about beloved or about individuals' not being appreciated during the era. This concept was mostly employed in the context of lover/belowed relationship. In this context, the beloved one is usually disloyal while the lover is a complete opposite. Mahmud Nedim Pasha is one of the poets who employs the notion of loyalty in a great deal. In fact, he is one of rare poets usig the word fidelity in a rhyme in the centuries-old tradition of classical Turkish poetry. The use of the concept of loyalty, which we encounter in many couplets in his diwan, as the word after the rhyme in two ghazals and chorus in two musammats, makes us think that we will gain important clues about the poet's unsteady period, political identity and life. The fact that he used the concept of loyalty in
\end{abstract}

1 Dr. Öğr. Üyesi, Kırklareli Üniversitesi, Fen Edebiyat Fakültesi, Türk Dili ve Edebiyatı Bölümü (Kırklareli, Türkiye), niyaziadiguzel@gmail.com, ORCID ID: 00oo-0001-9747-7734 [Makale kaylt tarihi: 18.11.2019-kabul tarihi: 20.12.2019; DOI: $10.29000 /$ rumelide.656691] 
his poems as the word after the rhyme and chorus as well as in many couplets gives the answer to why we chose this poet in classical Turkish poetry.

Keywords: Classical Turkish literature, fidelity, lover-beloved, Mahmûd Nedîm Pasha.

\section{Giriş}

Vefa kavramı; sevgi, paylaşım, dürüstlük, şefkat, hoşgörü, tevazu ve adalet gibi insanî değerlerin başında gelir ve bütün bu değerlerin anahtarıdır. Bunun yanı sıra merhamet, iyilik, hatır bilmek gibi duygular; tevekkül ve ibadet gibi uygulamalar da vefanın meyveleri sayllırlar.

Sözlüklerde vefa kavramıla ilgili sözü yerine getirme, ahdinde durma, kâfi gelme, dostlukta muhabbette sebat gösterme (Devellioğlu, 2009:1143-Naci, 1995:930); sözde durma, taahhüdü veya borcu ifa ve eda etme, ödeme: ahde vefa; muhabbette sadâkat ve devam ve sebat; bî-vefâ: vefasız; yetişme, kifayet, kâfi vâfî olma (Sâmi, 2015:1156) gibi tanımlar yapılmakta bunun yanı sıra dostluğunda sabit ve sadık olmaya vefâdârî; böyle davranana da vefâdâr (Sâmi, 2015:1157) kimse denilmektedir. Ayrıca hukukta, vefa hakkı denilen bir hak vardır ki bu hak, hak sahibine sattığı şeyin mülkiyetinin belli bir bedel karşılığında tekrar kendisine devrini, tek taraflı irade beyanıyla isteme yetkisi veren haktır. (Hukuk Sözlüğü)

Vefa kavramı tasavvufî olarak ruhu gaflet uykusundan uyandırmak, zihni dünya dağdağası ile meşgul etmemek, ruhun dürüstlük içinde bulunması, ezelde, bezm-i elestte Allahü Teâla'ya verilen söze, misaka bağlı kalmak ve insanlara verilen ahdi korumak (ahde vefa) (Uludağ, 1995:562) anlamlarında kullanılmıştır. Ahmet Rıfat Tasvîr-i Ahlak isimli eserinde kişinin şerefini arttıran iyi alışkanlıkların en başında vefanın geldiğini (t.y:365) söyler.

Kur'an-ı Kerîm'de "Size in'am ettiğim nimetimi hatırlayın ve ahdime vefa edin ki ahdinize vefa edeyim." "2 buyrulmaktadır. Hadis-i Şerif'te de Peygamber Efendimiz (s.a.v.) şöyle buyurmuştur: Beş şey vardır ki cezası dünyada hemen verilir: Zulmetmek, hainlik etmek, anne babaya eziyet etmek, akrabalarla ilişkiyi kesmek ve yapılan iyiliği görmemek (vefasızlı)3

Hemen hemen her dönemde insanlar zulüm, hainlik ve anne babaya eziyetle eş değerde tutulan vefasızlıktan yakınmışlar; sadık bir dost bulamamaktan, insanların bencil davranışlarından ve unutulmaktan dert yanmışlardır. Oysa erdemli ve fazilet sahibi bir kişi olabilmek vefalı olmaktan geçer. Vefalı olan kişi kendisine güven ve emniyet duyulan ve dostlukta da aranılan kişidir.

Edebî ürünler toplumların aynasıdır. Dolayısıyla şair ürettiği eserlerle, âdet, gelenek-görenek ve insanî değerleri yansıtma yönünde içinde yaşadı̆̆ toplumda önemli bir görevi de yerine getirmiş olur. $\mathrm{Bu}$ nedenle vefa kavramı da edebî eserlere konu olmuş ve özellikle şairlerce sıklıkla kullanılmıştır.

\section{1-Klasik Türk edebiyatında vefa kavramı}

Klasik Türk edebiyatında en sık tekrar edilen kavramlardan biri de vefadır. Âşık-maşuk ilişkisi vefa kavramı etrafında belirginleşir. Şairlerin ele aldığı sevgili tipi genellikle vefasızdır. O âşığına acı ve ıstırap verirken rakibe meyleder. Buna karşılık âşık vefalıdır, sevgilinin tüm acı ve ıstıraplarına karşı canını bile vermeyi göze almıştır. Bazen de sevgili âşığın canını ne kadar yakarsa o kadar vefalı; âşık da sevgilinin 
tüm acı ve ıstıraplarına karşı ne kadar dayanıklıysa o derece vefalı olarak kabul edilir. Aşağıdaki beyitte de görüldüğü üzere âşığın sevgiliye gösterdiği vefaya karşılık olarak sevgili âşığa bin kat cefa eder:

Ol yâre Ahmedî niçe kim çoh vefâ ider

Her bir vefâsına anuñ ol biñ cefâ ider (Ahmedî G.139/1)

Sevgilinin eziyeti aslında âşı için bir lütuftur ve bu onun aslında sevgi ve vefasının da bir göstergesidir. Bu nedenle âşık, edilen cefaları vefasızlık olarak değil de ihsan olarak görmelidir:

Didüm ana ey bî-vefâ nedür bu itdügün cefâ

Didi ki bil ey mübtelâ benden sana oldı atâ (Muhibbî G.30/1)

Sevginin olmadığı yerde vefadan bahsetmek yersizdir. Âşık için sevgi karşılıksız, beklentisiz ve sınırsız olmalıdır. Çünkü kişi sevdiğini her hâliyle ve her durumda sevebilmelidir. Bu nedenle zorluk zamanlarında âşığın sevgi, sadakat ve vefası daha iyi ortaya çıkmaktadır. Âşı asla cefadan yüz çevirmemeli ve daima sevgiliye yalvarmalıdır çünkü âşığa niyaz maşuka da naz yakışmaktadır:

Vefâ ummaz cefâdan yüz çevürmez Bâkî âşıkdur

Niyâz etmek ana cânâ yaraşur sana istiğnâ (Bâkî G.6/5)

Klasik şiirde şairler bazen dünyadan, zamandan ve felekten şikâyet eder ve dünyada zerrece vefa bulunmadığını söylerler. Bu anlamda dünyanın vefası bile vefasızlık olarak değerlendirilir. Fuzûlî Leylâ vü Mecnûn mesnevisindeki bir beytinde dünyada kimden vefa umduysa hep cefa gördüğünü ve dünyayla beraber içindekilerin de ne derece vefasız olduğunu veciz bir şekilde şöyle ifade etmektedir:

Vefâ her kimseden kim istedim andan cefâ gördüm

Kimi kim bî-vefâ dünyada gördüm bî-vefâ gördüm (Fuzûlî LM.1485)

Aslında dünyada vefa aramak boş bir uğraştır. Çünkü alçak dünyanın vefası, ayrılık Kafdağı’nda günlerini geçiren Anka gibidir. Anka, Kafdağı'nda yaşadığı var sayılan, tüyleri renkli, yüzü insana benzer, asla yere konmayıp daima yükseklerde uçan ve kendisinde her kuştan bir alamet bulunduran, adı var kendi yok (Pala, 1989:36) hayalî bir kuştur. Dolayısıyla onu bu ana kadar görmüş herhangi bir kişi yoktur. Böyle boş bir hayale ancak gafil olan kapılır. Akıllı olan kişi dünyada vefa aramaz:

Cefâ ile günümüz geçdi Kâf-ı fürkatde

Vefâ didikleri Ankâdur anı görmiş yok (T.Yahya G.208/2)

Tâlib-i Sîmurg u iksîr olma ey gafil sakın

Âkil isen dünyede yâr ü vefâ-dâr isteme (Nev'î G.420/4)

Âşık, sevgiliye kavuşamamaktan değil hayaline bile ulaşamamaktan yakınır. Çünkü her daim unutulduğunu düşünmektedir. Demek ki vefasız sevgilinin hayali de vefasız olur:

Unuttı hayli zamândur Nahîfî bendesini

O meh hayâli gibi bî-vefâ imiş hayfâ (Nahifî G.10/5)

Âşık dertli olduğu için her daim derdine derman arar ancak derdinin devası Anka gibidir, yani yoktur. Vefasız dünyada zaten vefa aramak da yersizdir: 
Adı var kendüsi yok tımarınun Ankâ gibi

Der cihân-ı bî-vefâ mânend-i u-râ kes ne-dîd4 (T.Yahya K.29/29)

Eğer deva aranacaksa ayrılık derdinin kavuşmayla giderildiği gibi vefaya karşı eziyet ve cefa en tesirli ilaçtır. Aşağıdaki beyitte şair Fıtnat Hanım, aslında bu dünyada her derdin mutlaka bir devasının da bulunduğunu şöyle dile getirmektedir:

Cevr ü cefâya mihr ü vefâ firkate visâl

Her derdin ey gönül bu cihânda devâsı var (Fıtnat Hanım G.17/4)

Vefa kelimesi bazen de İstanbul'da bir semt ismi olarak karşımıza çıkmakta ve semt anlamının da ima edilmesiyle birlikte tevriyeli biçimde çekilen cefaların son bulacağı mekân şeklinde kullanılmaktadır:

Kûy-ı cefâya mı çıkacak hep güzer-gehüñ

Semt-i Vefầya hiç güzerüñ yok mıdur senüñ (Kânî K.37/31)

Kaynaklara göre klasik Türk şiirinde Vefa mahlaslı üç ve Vefâî/Vefâyî mahlaslı dört şair mevcuttur. (İpekten, 1988:526-527; İnal,1941:1967-1970; Türk Edebiyatı İsimler Sözlüğü). Bunların yanı sıra Osmanlı sultanlarından Sultan IV. Mehmed'in de şiirlerinde Vefâî mahlasını kullandığını göz önünde bulundurursak, klasik Türk şiirinde toplam sekiz şairin vefa kavramıla kendilerini ilişkilendirmiş olduklarını ve mahlas olarak "Vefa"yı seçtiklerini görürüz. Bu şairlerden hiçbirinin divanının elimizde olmayışı, şairiyle mahlas olarak seçtiği vefa kavramı arasında ne gibi bir ilişki olduğu konusunda sağlıklı bir değerlendirme yapmamızı mümkün kılmamaktadır.

Klasik Türk şiirinde tüm şairler vefa kavramını az ya da çok şiirlerinde kullanmışlardır. Ancak bu kavramı özellikle redif olarak kullanan pek az şair vardır. Bunlardan biri de Osmanlı'nın son döneminde iki defa sadrazamlık görevinde bulunmuş olan Mahmud Nedim Paşa'dır. Her ne kadar mahlas olarak Nedim ismini tercih etmişse de onun şiirlerinde vefa kavramını çok sık kullanmış olması ayrıca dikkate değer bir husustur. Divanında vefa ve vefa kavramıyla ilişkili yüze yakın beyit bulunan şairin biri vefa diğeri vefa va'dim redifli iki gazeli de mevcuttur. Bunların yanı sıra iki musammatında aşığa ma'şûkdan olmaz vefâ ve senin ey bî-vefâ feryâd elinden nakaratlarını tercih etmiştir. Yine nesir olarak kaleme aldığ 1 Âyine-i Hasbihâl isimli eserinde devlet idaresine dair düşüncelerini maddeler halinde ele almış ve nasihatlerde bulunmuştur. Bu maddelerden birisi de sebattır ve bu başlık altında vefayı vurgulayarak sözünde, işinde, mesleğinde ve vaadinde ahde vefa etmek gerektiği (Kaya, 2015:82) üzerinde durmuştur. Onun bu tercihleri aslında bu kavrama ne kadar önem verdiğinin de göstergesidir.

Mahmud Nedim Paşa, sadrazamlık görevi esnasında sık sık memurların yerlerini değiştirmesi, tenkihât ve tasarrufât adı verilen memurların maaşlarında kesintiler yapması, bazı önemli devlet adamlarının görevlerine son vermesi, vilayet sistemini değiştirerek bazı illerde değişiklik yapması, Osmanlı borçlarının faiz ve anapara ödemelerinin beş yıl süreyle yarıya indirilmesi gibi icraatları nedeniyle içerden ve dışarıdan çok fazla tepki almış ve birçok düşman edinmiştir. Eserlerinde özellikle de divanında bu derece vefayı vurguluyor olması devrinin karmaşı yapısı ve çalkantılı geçen (siyasî) hayatıyla şiiri arasında bir paralellik olup olmadı̆̆ı sorusunu akla getirmektedir. Bu nedenle çalışmada öncelikle şairin hayatı ve eserleri hakkında bilgi verilmiş, sonra vefa kavramının divanda ele alınışı başlıklar altında incelenmiştir.

4 Vefâsız dünyada onun gibisini kimse görmedi. 


\section{2-Mahmud Nedim Paşa}

\subsection{Hayati5}

Tanzimat döneminin önemli devlet adamlarından biri olan Mahmud Nedim Paşa, 1817 yllında İstanbul'da doğdu. İyi bir eğitim alarak küçük yaşta devlet hizmetine girdi. 1847 yllında dönemin önemli devlet adamlarından biri olan Mustafa Reşit Paşa'nın dikkatini çekerek Sadaret Mektupçuluğuna getirildi. Daha sonra Âmedîlik ve Beğlikçilik vazifelerinde bulundu. 1854 yılında Hariciye ve Sadaret müsteşarlıklarında bulundu. 1855 yılında Mustafa Reşit Paşa'nın yardımıyla vezirlik rütbesi verilerek Sayda Valiliği'ne atandı. Şam ve İzmir Valiliklerinde ve Hariciye Nezareti Vekâleti görevlerinde bulundu. 1860 yılında kendi isteğiyle Trablusgarb Valiliği’ne gönderildi. 1860-67 yılları arasında 7 yıl bu görevde bulundu. Bu görevden sonra 1867'de Şûrâ-yı Devlet Âzâlı̆̆ı'na, Deâvî Nazırlığına ve Bahriye Nazırlığına atandı. 1871 yılında Ali Paşa'nın ölümü üzerine ve padişahla kurduğu irtibat sayesinde sadrazam oldu. 11 ay süreyle bu görevi sürdürdü. Bu dönemde isyanlar ve yabancı devletlerin müdahaleleri artmış maliye iç ve dış borçlar yüzünden iflasın eşiğine gelmişti. Böyle bir kriz döneminde sadarete getirilen Paşa, halefleri olan Ali ve Fuad Paşaların aksine devlet idaresinde padişahın daha etkin bir rol oynamasını istiyordu ve bu nedenle Babıali merkezli kurulan idari yönetimi padişah lehine değiştirmeye çalıştı. Saray eksenli bir idare ve padişahın otoritesini güçlendirici faaliyetlerde bulundu. Merkez ve taşra teşkilatlarında büyük bir operasyon başlatıp Tanzimat devlet adamlarını görevden uzaklaştırdı. Ancak kendisine rakip olan diğer devlet adamları onun sadareti döneminde devletin ve milletin zarar gördüğünü iddia ederek yargılanmasını istediler. Padişah tarafından görevden alındı. Hakkında gazetelerde olumsuz haberler çıktı ve Bebek'te bulunan yalısı önünde halk tarafından aleyhinde gösteriler yapıldı. Azledip Kastamonu valiliğine gönderilmişken tekrar İstanbul'a çağrıldı. Ancak Sultan Abdülaziz önceki emrinden vazgeçip yargılanmadan Trabzon'a sürgüne gönderdi. 4 ay Trabzon'da kaldıktan sonra 1873'te Adana Valiliği’ne atanan Paşa, bu sırada bir türlü çözüm bulunamayan Hersek isyanını kısa sürede çözebileceğini belirtmesi üzerine 1875 yılında ikinci defa sadaret makamına getirildi. İkinci defa geldiği sadaret makamındaki görev süresi 8,5 ay sürmüştür. Bu dönemde uyguladığı Osmanlı borçlarının faiz ve anaparalarının beş yıl süreyle yarıya indirilmesi kararı, yerli yabancı birçok tahvil sahibini zarara uğrattığı için Paşa'ya karşı büyük bir tepki doğurmuştur. Hersek ve Bulgar isyanıyla beraber Fatih, Süleymaniye ve Bayezid Medreselerinde okuyan çoğu Rumelili talebenin derslerini bırakarak gösteriler yapması da bir nevi isyana dönüşmüş bütün bu olaylar diğer siyasî aktörlerin de kışkırtmasıyla Mahmud Nedim Paşa hükümetinin düşmesine ve Paşa'nın sadaretten uzaklaştırılmasına sebep olmuştur. Hastalığı nedeniyle kendi isteğiyle bir müddet Çeşme'ye sonra Sakız'a gönderilen Paşa daha sonra Sultan II. Abdülhamid'in tahta çıkmasıyla affını istedi ve sultanın davetiyle tekrar İstanbul'a geldi. 1879 yılında Küçük Said Paşa kabinesinde Dâhiliye Nazırlığı görevine getirilen Paşa, ölümüne kadar yaklaşık 3 yll bu görevi sürdürdükten sonra 1883 yllında vefat etti.

Mahmud Nedim Paşa'nın sadareti zamanında yaptığı ve çokça eleştirilmesine sebep olan en önemli uygulamalardan biri devletin çeşitli kademelerinde bulunan büyük küȩük birçok memurun görev yerinin değiştirilmesidir. Bu dönemde memurlardan kimi emekliliğe sevk edilip kimi de azledilmiştir. Tasarruf yapılacak diye birçok memurun işine son verilmiş, bu durum Paşaya karşı büyük bir nefret ve kinin doğmasına sebep olmuştur. Bir başka eleştirilen yönü ise Rus yanlısı bir politika izlemesidir. Tanzimat'la

Bu bölümün hazırlanmasında şu kaynaklardan yararlanılmıştır: Akyıldız, Âli. (2003) Mahmud Nedim Paşa TDV İslam Ansiklopedisi, C. 23, s.374-376; Pakalın, Mehmet Zeki. (2016) Mahmud Nedim Paşa Ankara: Divan Kitap; İnal, İbnülemin M. Kemal. (1982) Son Sadrazamlar, Cilt I, s.259-314; Kaya, Gökhan. (2015) Bürokratik Nüfûza Karşı Monarşik Egemenliği Yeniden Kurgulamak Üzerine Bir Girişim: Mahmud Nedim Paşa'nın Görüşlerinde Ahlak ve Devlet İdaresi OTAM, 38 Güz 2015 s.55-94; Polat, Mustafa. (2003) Mahmud Nedim Paşa Sakarya Üniversitesi Sosyal Bilimler Enstitüsü Yayımlanmamış Yüksek Lisans Tezi; Sadıkoğlu, Sevil. (2013) Mahmud Nedim Paşa'nın Bürokraside Gerçekleştirdiği Büyük Tenkihat Marmara Üniversitesi Türkiyat Araştırmaları Enstitüsü Yayımlanmamış Yüksek Lisans Tezi. 
beraber genelde devlet adamları güçlü bir Avrupa devletinin politikalarıyla yakın durma eğilimine girmişlerdi. Mustafa Reşit Paşa İngiliz, Ali ve Fuad Paşalar Fransız yanlısı bir tutum içindeyken Mahmud Nedim Paşa Rus yanlısı bir politika izlemiştir. Bu nedenle Rus elçisi İgnatiyef'in her istediğini yerine getirdiğini düşünenler ona "Nedimof" lakabını takmışlardı.

Paşa’ya duyulan tepkilerin bir diğer sebebi de Osmanlı borçlarının faiz ve anaparalarının beş yıl süreyle yarıya indirilmesidir. Bu karar yerli yabancı birçok tahvil sahibini zarara uğrattığı için kendisine karşı büyük bir tepki doğmuştur.

Ahmet Mithat Efendi'nin Üss-i İnkılap adlı eserinde Mahmud Nedim Paşa'yı Abdülaziz dönemindeki bütün olumsuzluklardan sorumlu tutması üzerine ona Müdafaaname isimli eserinde cevap veren Mahmud Nedim Paşa, 16 seneden fazla süren bir saltanat asrının bütün olumsuzluklarının kendisine isnat edilmesinin çok insafsız bir durum olduğunu belirtmiştir.

Memurların yerlerini değiştirmesi, tenkihât ve tasarrufât adı verilen memurların maaşlarında yapılan kesintiler ve bazı önemli devlet adamlarının görevlerine son vermesi bunun yanı sıra önceki bazı devlet adamları gibi İngiliz ve Fransız yanlısı olmayıp Rusya taraftarı olması, vilayet sistemini değiştirerek bazı illerde değişiklik yapması en fazla eleştirilen yönleridir. Ayrıca Osmanlı borçlarının faiz ve anapara ödemelerinin beş yll süreyle yarıya indirilmesi içerden ve dışarıdan birçok tepki almasına sebep olmuştur. Bütün bu nedenlerden ötürü sadrazamlı görevi süresince ve sonraki yaşamında sürekli eleştirilmiş, birçok düşman edinmiş ve siyasî hayatı inişli çıkışlı bir seyir izlemiştir. Özellikle rakipleri tarafından vehimli, dönek, sebatsız, fesatçı ve rüşvetçi bir kişiliğe sahip olduğu bile iddia edilmiştir.

\subsection{Eserleri}

Mahmud Nedim Paşa'nın Âyine-i Devlet (Âyine-i Hasbihâl), Reddiye (Müdâfaanâme), Hikâye-i Melik-i Muzaffer isimli eserleri ve şiirlerini topladığı Dîvân'ı bulunmaktadır. Âyine-i Devlet'te devlet yönetimini incelemiş ve devlet adamlarında bulunması gereken vasıfları başlıklar halinde ele almış ayrıca mali konulara da yer vermiştir. Âyine-i Hasbihâl ise bu kitaba birleştirilmiş manzum bir eserdir. Reddiye isimli eserini ise Ahmed Mithat Efendi tarafından kaleme alınan Üss-i İnkılap adlı kitaba cevaben yazmış ve kendi sadareti zamanında yapılan işlerin doğruluğunu savunmuştur. Bir diğer eseri olan Hikâye-i Melik-i Muzaffer'i Trablusgarb Valiliği sırasında kaleme almış ve devletin gerileme ve ilerlemesinin ne şekilde olabileceği ve nasıl ıslah edileceği hakkında görüşlerini belirtmiştir.

Mahmud Nedim Paşa'nın edebî yönünü yansıtan en önemli eseri ise divanıdır. Dîvânı'nda 23 Kaside, 235 Gazel, 29 Murabba, 9 Muhammes, 2 Müseddes, 8 Tahmis, 6 Tarih, 23 Nakıs Gazel, 10 Kit'a, 1 Mütali, 16 Müfred ve 44 Mısra bulunmaktadır. Tek nüshası Millet Kütüphanesi Ali Emiri Tasnifi No: 435'te bulunan Dîvân'ı, M. Akif Kürkçüoğlu, tarafından 2003 yılında Mahmûd Nedim Paşa Dîvânı İnceleme, Transkripsiyonlu Metin, Sözlük ismiyle Yüksek Lisans Tezi olarak hazırlanmıştır.

\section{3-Mahmud Nedim Paşa Divanı'nda vefa kavramı ${ }^{6}$}

Mahmud Nedim Paşa, divanında sık sık vefa kavramını dile getirmektedir. Bu kavramı sadece birkaç beyitte değil de özellikle gazellerin rediflerinde tekrar tekrar vurguluyor olması, onun aslında inişli

\footnotetext{
6 Bu çalışmada Mahmud Nedim Paşa Divanı’nın M. Akif Kürkçüoğlu tarafından hazırlanan metni ( Mahmûd Nedim Paşa Divanı İnceleme, Transkripsiyonlu Metin, Sözlük. Sakarya Üniversitesi Sosyal Bilimler Enstitüsü, Yayımlanmamış Yüksek Lisans Tezi 2003) esas alınmış, bazı beyitlerde karşılaşılan vezin hataları ve okuma yanlışları tarafımızca düzeltilmiştir.
} 
çıkışlı hayatında ne kadar da çok vefaya ihtiyaç duymuş olduğunu hissettirmektedir. Bu duygunun bir tezahürü olarak divanında toplam dört manzumede redif ve nakarat olarak vefa kavramını kullanmıştır. Bunlardan ilki gazeliyyât bölümündeki 8. gazelidir. Şair bu şiirine, bütün hayat tecrübesiyle beraber işin sonunda vefanın kuru bir hayalden ibaret olduğunu anlayarak aslında hatanın vefasızlık yapanda değil de vefa talep edende olduğunu dile getirerek başlamaktadır:

Encâm-ı kâr oldu kuru hulyâ vefâ

Gûyâ ki mün‘adim idi sûret-nümâ vefâ (G.8/1)

Hükm-i zamâne dikkat edip şimdi anladım

Bildim anı ki heb arayanda hatâ vefâ (G.8/2)

Şaire göre vefayı ortaya çıkarmak terk ve fedakârlığa bağlıdır. Yani vefanın değeri ancak terk edilmesiyle olur. Aslında çekilen bütün cefalar kişide bir nevi anestezi uygulaması gibi tesir eder. Bunun sonunda bütün uzuvlar uyuşturulur ve böylece şevkin neşesi ortaya çıkar:

İhdâr ile ta'ayyün eder neş'e-i şevk

Takdîr olur mu olmasa terk u fedâ vefâ (G.8/3)

Şairin gözünde safa ve vefa iki arkadaş gibidir. Âşık zanneder ki sevgilide vefa duygusu olmadığı için ona böyle yabancı gibi davranmaktadır. Oysaki bu bir sınamadır. Çünkü yabancı gibi davranan aşinalar vardır. Âşık onları terk etmeli, çekilen cefaları canına minnet bilip baş üstünde tutmalıdır. Ancak böyle yaparak vefayla safanın arkadaş olduğu bilincine varılır:

Bî-gâne âşinâsına âlemde bî-karar

Zannım odur ki yârdan olmuş cüdâ vefâ (G.8/4)

Bî-gâne âşinâları terk eyledim Nedîm

Pâdâşdır benimle hemîşe safâ vefâ (G.8/5)

Mahmud Nedim Paşa'nın vefâ va'dim şeklinde redif kullandı̆̆ı vefa kavramını içeren diğer bir şiiri de divanındaki 120. gazelidir. Toplam 8 beyitten oluşan bu gazelinde şair düşünce boyutunda vefa vaadinin hayalden ibaret olduğunu ve bu kavramın ince ve dikkatli bir bakış tarafından asla fark edilemeyeceğini söyler. Ayrıca vefa vaadinin kesret yani ikilik gibi görünmesine karşıllk ibret aynasında vahdet olarak yansıdı̆̆ını belirtir:

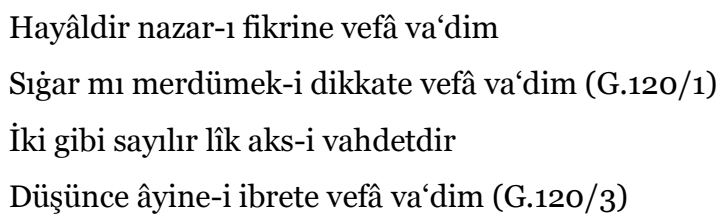

Şaire göre vefa vadinde bulunmak mutlak anlamda bir kuruntudur. Çünkü vefa vaadinde bulunmak Hüma kuşunun gölgesi gibidir. Bilindiği üzere Hüma; devlet kuşu, talih kuşu olarak da bilinen efsanevî bir kuştur. Eskiden bir meydanda uçurulur ve kimin başına konarsa o kişi padişah olurmuş. Yine göklerde uçunca gölgesi kimin başına düşerse o kişi ilerde padişah olurmuş (Pala, 1989:238). Bütün bu zorluklardan dolayı vefa vaadinde bulunmak güç ve akıldan uzak bir vaattir: 
Misâl-i zıll-ı hümâ vehm-i mahz u mutlakdır

Ba`îddir hired u miknete vefâ va‘dim (G.120/5)

Şair vefa vaadiyle vuslatın bir birine zıt kavramlar olduğunu düşünerek birinin gelmesiyle öbürünün gideceğini söylemektedir. Ona göre kavuşma meclisine ancak yoklukla erişilir:

Biri yok olsa biri var olub da ey Nedîm

Geleydi encümen-i vuslata vefâ va'dim (G.120/6)

Tüm bu değerlendirmelerden sonra şair gazelin son beytinde hayal gücünü Çinli meşhur nakkaş Mani'ye benzeterek hüner göstermek kastıyla bu şiiri yazdığını ve varlığı olmayan vefa vaadine adeta vücut verdiğini dile getirmektedir:

Edince kasd-ı hüner Mâni-i hayâl-i Nedîm

Vücûd verdi meger sûrete vefâ va'dim (G.120/8)

Mahmud Nedim Paşa'nın hırs, düşkünlük, tama' gibi kelimelerle âşı̆̆ı nitelendirdiği, vefa kavramını vurguladığı ve bizce çalkantılı siyasi hayatının divanındaki yansımalarını en iyi gösteren şiirlerinden biri de "âşı̆̆a ma'şûkdan olmaz vefâ" nakaratlı musammatıdır. Bu musammatında şair, hırs ve düşkünlük arttıkça sıkıntıların da artacağını ve âşığa maşuktan hiç bir zaman vefa olmayacağını dile getirir:

Ber-ziyâd oldukça hırs u ibtilâ

Fehm eder elbet anı ol pür-cefâ

Bu sözü inkâr eden varsa hâlâ

Âşıka ma‘şûkdan olmaz vefâ (Mus.5/1)

Ona göre maşuktan visal temennisinde bulunmak ona bıkkınlık vereceğinden vefa beklentisinde olmamak gerekir:

Ey gönül her-dem temennî-i visâl

Eyleyib ma'şukuna verme kelâl

Kendi tavrından biraz da ibret al

Âşıa ma'şûkdan olmaz vefâ (Mus.5/2)

Şair âşığa seslenip maşuktan gelecek ihsanlara her daim göz dikmemesi gerektiğini söyleyerek ancak bu şekilde kavuşma arzusuna yüzünün olabileceğini belirtir. Bu ihtimale karşı yine de sözün doğrusu şudur ki âşığa hiçbir zaman vefa yoktur:

Her zamân ihsânına dikme gözüñ

Ârzû-yı vuslata olsun yüzüñ

Doğrusun ister isen benden sözüñ

Âşıka ma‘şûkdan olmaz vefâ (Mus.5/3)

Bir diğer musammatında da şair, vefasız sevgiliden dolayı gönlünün harap, ciğerinin yaralarla dolu olup bağrının parça parça ve ağlamaktan gözlerinin bile yara olduğunu dile getirerek vefasız sevgiliden bir türlü kurtulamadığından bahisle feryat etmekte ve halinin çok kötü olduğunu söylemektedir: 
Harâb oldu dil-i nâşâd elinden

Seniñ ey bî-vefâ feryâd elinden

A zâlim olmadım âzâd elinden

Seniñ ey bî-vefâ feryâd elinden (Mus.15/1)

Ciger pür-şerha bağrım pâre pâre

Figanımdan dü-çeşmim oldu yâre

Nedir kasdıñ seniñ uşşâk-ı zâre

Seniñ ey bî-vefâ feryâd elinden (Mus.15/3)

Nedir bu cevriñ ey şûh-ı dil-âzâr

Neler çekdi elinden âşık-ı zâr

Nedîmiñ hâli oldu şimdi düşvâr

Seniñ ey bî-vefâ feryâd elinden (Mus.15/4)

Şairin bu manzumeler dışında divanında parça parça bulunan ve vefa kavramını içeren çok sayıda beyit mevcuttur. Bu beyitleri kendi arasında tasnif ederek belli başlıklar altında şöylece değerlendirmek mümkündür.

\subsection{Vefa kavramının olumlu anlamda kullanımı}

Şair vefa kavramını klasik Türk şiiri şairleri gibi genelde olumsuz anlamıyla kullanmıştır. Ancak nadiren de olsa olumlu anlamda kullandığı bazı beyitler mevcuttur. Vefayı olumlu anlamda ilk olarak kullandığı yer kasideler kısmında Peygamber Efendimize (s.a.v.) yazmış olduğu naatin 13. beytidir. Bu beyitte Peygamber Efendimiz'i (s.a.v.) vefa ikliminin şahı olarak nitelemekte ve O'nun bütün günahkâr ve asi kullara yardım ulaştırdığını dile getirmektedir:

Şâhen-şeh-i iklîm-i vefâ kân-ı atâsın

Mücrimlere âsilere imdâd-resâsın (K.6/13)

\subsubsection{Dost ahdinde vefalı olmalıdır}

Aslında şair, kişinin her daim vefakâr olması gerektiğini düşünmektedir. Ona göre dost dediğin verdiği sözü yerine getirmelidir. Çünkü muhabbetin açığa çıkması doğruluğa yani vefalı olmaya bağlıdır:

Ahdinde vefâ-dâr gerek yâr Nedîmâ

Doğruluğa peyvestedir ikrâr-ı muhabbet (G.21/8)

\subsubsection{Sevgilinin her bir tavrı vefa göstergesidir}

Aslında âşı için ister eziyet ister iyi muamele olsun sevgilinin her bir tavrı vefa göstergesidir. Şair aşağıdaki beytinde vefa ve cefa kelimeleriyle cinâs-ı lâhik sanatına da yer vererek bu durumu şöyle ifade etmektedir:

Demem ki yâr elinden gönül cefâ gördüm

Teşekkür etmedeyim dâimâ vefâ gördüm (G.115/1) 


\subsection{3. Âşığın gönlü sükûnet bulmuştur}

Sevgiliden gelen her bir tavrı vefa göstergesi olarak gören âşı̆ın gönlü, sevgilinin tavırları karşısında artık sükûnet bulmuştur. Ancak buna rağmen gönlünde bazı şüpheler de yok değildir. Bu nedenle âşık gönlündeki şüphelerle her daim mücadele halindedir:

Vefâ-yı yârde göñlüm bulunca itmînân

Rekâbet etmededir iştibâhdan gelene (G.167/4)

\subsection{Vefa kavramının olumsuz anlamda kullanımı}

Klasik Türk şiirinde olduğu gibi Mahmud Nedim Paşa da geleneği devam ettirmiş ve vefa kavramını çoğunlukla olumsuz anlamıyla kullanmıştır. Mutlak anlamda vefanın olmadığını söyleyip Kaf, Anka ve Hüma kuşu benzetmesiyle bu değerin çok uzaklarda olduğunu vurgulamış ve sevgilinin tüm vefasızlıklarına karşılık âşığın çektiği çileleri dile getirmiştir.

\subsubsection{Mutlak anlamda vefanın yokluğu}

Şaire göre bu fikir ve emel dünyasında vefa aramak yok olan bir şeyin peşine düşmek demektir. Yaptığı bu davranıştan dolayı kendisi de şaşkın bir vaziyettedir. Kendisine seslenerek ne ilginç bir durum ki yoğu var olarak saymaktayım diyor:

Cihân-ı fikr u emelde vefâ arar gezerim

Aceb aceb ki baña yoğu var farz ederim (G.127/6)

Ona göre aşk âleminde vefa bulmak yoğu var etmek demektir ki bu da oldukça şaşlacak bir durumdur. Oysa gönül vefa ümidinden vazgeçmelidir. Çünkü olmayan bir şeyi vücuda getirmek imkânsızdır:

Âlem-i aşk için vefâ bulurum

Ne acebdir ki yoğu var ederim (G.114/7)

Gönül ümmid-i vefâdan ferâgat etmelidir

Vücûd vermege kâbil midir muhâle hayal (G.109/4)

Aslında şair, şu dünya gül bahçesinde vefa kokusu veren bir arzu goncasının hiçbir zaman açılmamış olduğunu düşünmektedir:

Zannım odur ki gülşen-i dehre açılmadı

Ol gonce-i merâm ki bû-yı vefâ verir (G.53/4)

\subsubsection{Kaf Anka ve Hüma benzetmesi}

Şair vefayı, Kafdağı'nda yaşadığına inanılan Anka gibi görmektedir. Zaten halkın lisanında vefa dedikleri şey aslında neşe Kafdağı'nda bulunan Anka kuşudur. Bilindiği üzere Kafdağı dünyayı çevrelediği düşünülen bir dağ silsilesinin adıdır. Anka da orada yaşayan hayalî bir kuştur:

Lisân-ı âleme düşmüş adı vefâ derler

Bu Kâf-ı neş'ede Ankâ dahi aña derler (G.38/1) 
Dünyada Anka gibi olan o vefayı zaten bir gören yoktur. Çünkü onun her ne kadar ismi konmuşsa da cismi yoktur:

Dünyâda vefâyı acebâ var mı görenler

Anka gibi bir mün‘ademe var adı konmuş (G.86/2)

Şaire göre vefa vaadinde bulunmak Hüma kuşunun gölgesi gibidir. O gölge kimin üzerine düşerse başına devlet kuşu konmuş olur. Ancak bu çok zor gerçekleşecek bir durumdur. Böyle düşünmek kuruntudur ve akıldan uzak güç bir ihtimaldir:

Misâl-i zıll-ı hümâ vehm-i mahz u mutlakdır

Ba`îddir hired u miknete vefâ va‘dim (G.120/5)

\subsection{Sevgili vefa ilişkisi}

\subsubsection{Vefasının olmayışı/yokluğu}

Şaire göre sevgilide vefa yoktur. Olmayan bir şeyi aramaksa beyhudedir. Hal böyle olunca olmayan bir varlığı hayal ederek yâre vefasız demek de şaşılacak bir durumdur:

Vücûd-ı mün'adimin varlı̆̆ıñ hayâl ederek

Niçin niçin acebâ yâre bî-vefâ derler (G.38/2)

Safa ve vefa anları artık hayale dönüştüğü için o gönül çekici sevgilinin, gönül safasının kaynağı olduğu anlar hep geride kalmıştır:

Hayâle munkalib oldu dem-i vefâsında

Safâ-yı hâtıra ol dil-keşiñ medâr idügi (G.225/2)

\subsubsection{Vefasızlı̆̆ının göstergeleri}

Şaire göre sevgilinin âşı̆̆ını azarlaması aynı zamanda vefasızlı̆̆ının bir göstergesidir. Kuvvetli sezgisiyle bunu sezen âşık bu nedenle vefadan ümidini kesmelidir:

Yârde yokmuş vefâ âzârı iz ândır baña

Nâ-ümmîd olmak vefâdan ayn-ı irfândır bana (G.3/1)

Sevgilinin vefasız olduğunun bir diğer göstergesi de sürekli söz vermesi fakat sözünde durmamasıdır. Onun bu kararsız ve sebatsız tavrı karşısında âşık, yemin etse bile artık inanmayacak bir duruma gelmiştir:

Söze geldikde bezl-i lutf edersin

Yine semt-i vefâdan yan çizersin

Hele hercâillikde pür-hünersin

Yemin etsen de aldanmam inanmam (Mus.17/3)

Aslında sevgili sözünde vefalı gibi olsa da iç hali, tavır ve davranışları bunun tam tersini göstermektedir. Hal böyle olunca muhabbetle elde edilen kazanç sonunda ayrılığa dönüşmektedir: 
Sözünde vefâ olsa da sîret bozulunca

Hicrâna çıkar âkıbet kâr-ı muhabbet (G.21/4)

\subsubsection{Vefasızlığından şikâyet}

Klasik şiirde şairler sevgilinin vefasız oluşundan dert yanarlar. Mahmud Nedim Paşa da aynı dertten muzdariptir. Çünkü sevgilisi her daim vefasızlık yapıp onun bütün anını harap etmektedir. Ancak bundan daha fazla üzüldüğü ve hayıflandığı şey sevgilinin bir de isminin önüne vefalı sıfatının konmasıdır:

Her anı tebâh etmede cânân-ı Nedîm

Sad hayf ki cânâna vefâ-kâr adı konmuş (G.86/5)

Oysa ne insafsız ve mürüvvetsiz bir yâre düşmüştür. Onu gül zannederken yazıklar olsun ki dikenlerle karşlaşmıştır:

Ne insâfsız mürüvvetsiz vefâsız yâre düşdüm ben

Gülümdür zan ederken hayflar kim hâre düşdüm ben (G.138/1)

Şair, aşağıdaki dörtlüğünde, Vefa semtini de tevriyeli olarak kullanarak vefasız sevgilinin onun ilkbaharını sonbahara çevirdiğini, Vefa'yı bozulmuş bir bağa döndürdüğünü ve ona diken sunarken kendisinin safa sürdüğünü belirtiyor. Buna rağmen yine de ondan gülüm, gülşenim ve bülbülüm olarak bahsediyor:

Hazân-ı nev-bahâr etdiñ cefâyı

Bozulmuş bâğa dönderdiñ Vefâyı

Baña hâr olduñ ammâ gör sefâyı

Gülüm sen gül-şenim sen bülbülüm sen (Mus. 10/2)

Sevgiliden gelen bütün bu eziyet ve cefalar, kimilerince vefa olarak görülmektedir. Oysa şair bunu böyle görmeyip şu soruyu sormaktadır: Bu bir tevekkül müdür yoksa aşkın verdiği sersemlik midir?

Cânândan zuhûr-1 cefâya vefâ diyen

Aşkiñ belâheti mi tevekkül müsün nesin (G.145/4)

Sevgili, bütün bu yaptıkları yetmiyormuş gibi âşı̆̆ın bunca üzüntüsüne ek olarak bir de başkalarına meyletmektedir. Hal böyle olunca ondan vefa beklemek de âşık için pek mümkün gözükmemektedir. Bu nedenle sevgili artık yemin bile etse âşık ona inanmamaktadır:

Göñül sevdâ-yı aşkıñla üzülsün

Seniñ meyliñ yine ağyâre olsun

Vefâ me'mûli artık şöyle dursun

Yemin etsen de aldanmam inanmam (Mus.17/2 


\section{4. Âşık vefa ilişkisi}

\subsection{1. Âşı̆̆ın bütün arzusu vefadır}

Şaire göre muhabbet serüveninin ayrıntılarına girmek gerekmez çünkü onlar masaldan ibarettir. Onun bütün bu ayrıntılara girmeden sevgiliden tek bir beklentisi vardır o da vefadır:

Cânândan hulâsâ vefâdır emel Nedîm

Tafsîl-i mâcerâ-yı muhabbet fesânedir (G.39/5)

Şair sevgiliden vefanın gelip gelmeyeceğini bilememektedir. Ancak, içindeki şüphelerden kurtularak sevgiliden vefa ümidinde olduğunu dile getirir:

Vâreste-i hâtır olmuş idin iştibâhdan

Ümmîdimiz vefâ idi dâ'im o mâhdan (G.142/1)

Âşık kendisini sevgilinin vefalı oluşuna inandırmış ve bu durumu gönlünde de tasdik etmiştir. Ancak, onun vefasızlık anlarını görünce bu inancı sarsılmış, adeta imanı zedelenmiştir:

Vefâ-dârî-i cânân olmuş idi ayn-ı ikrârım

Vefâsızlık demin derk eyleyip îmândan geçdim (G.124/3)

Oysa şunu bilmelidir ki sevgili vefasızdır ve ondan vefa beklemek ayıtır. Böyle hayalî şeylere boşuna fikir yürütmemek gerekir:

Bî-vefâ ma'şûkdan ümmîd-i lutf etmek abes

Sarf-ı efkâr eylemem öyle hayâl-hâne ben (G.161/7)

\subsection{2. Âşığa asla vefa yoktur}

Âşı, bütün uğraşlarına rağmen sevgiliden bir türlü vefa görememektedir. Hatta âşığın bu ısrarları sevgiliyi rahatsız da etmektedir. Âşık şunu iyi bilmelidir ki ona hiç bir zaman vefa olmayacaktır:

Ey gönül her-dem temennî-i visâl

Eyleyib ma'şûkuna verme kelâl

Kendi tavrından biraz da ibret al

Âşık ama'şûkdan olmaz vefâ (Mus. 5/2)

Vefasız sevgiliden çektiği cefalar sonucu âşık, ah u figan etmektedir. Âşığın tek beklentisi, bu ahının sevgiliye tesir etmesi ve bu ayrılık derdine bir çare bulmasıdır:

Âhımdan ol vefâsıza te'sîr beklerim

Ammâ gam-ı firake de tedbîr beklerim (G.129/1)

Sevgilinin cefası aslında âşık için bir lütuftur ve vefasının da bir göstergesidir. Bu bilince varan âşı yapılan eziyetleri vefasızlık olarak değil de ihsan olarak görmelidir. Gönül alan sevgilinin her bir tavrı can ü gönülden hoş karşılanmalıdır. Çünkü muhabbet denizine dalan için vefa ve cefa birdir: 
Müstagrak-1 muhabbete birdir vefâ cefâ

Her tavr-ı dil-sitân ile ülfet gönüldedir (G.64/4)

\section{Sonuç}

Klasik Türk şiirinde vefa kavramına divanlarda sıklıkla yer verilmiş ve bu kavram çoğunlukla olumsuz yönüyle ele alınmıştır. Şairler genellikle, zaman, devran, felek ve dünyadan şikâyet edip bu dünyada hiç vefa bulunmadığını dile getirerek vefalı bir dost bulamamaktan dert yanmışlardır. Âşık-sevgili ilişkisinde de sevgili daima vefasız buna karşılık âşık vefalı olarak gösterilmiştir.

İnişli çıkışlı bir siyasî hayat geçiren Mahmud Nedim Paşa, görev yaptığı zamanlarda özellikle de sadrazamlık dönemindeki icraatlarıyla birçok rakip ve düşman edinmiştir. Kendisine muhalif olan devlet adamlarınca sürekli eleştirilmiş ve Sultan Abdülaziz (1861-1876) devrinde gerçekleşen bütün olumsuzluklardan sorumlu tutulmuştur. Kaleme aldığı mensur eserlerde bu eleştirilere cevaplar vermiştir. Divanındaki şiirler incelendiğinde de vefa kavramını çok sık vurgulamış olduğu görülerek bu durum sıkıntılı geçen siyasî hayatının bir yansıması olarak değerlendirilmiştir.

Paşa, divanında yüze yakın beyitte vefa kavramını kullanmış bunun yanı sıra gazel ve musammat nazım şekilleriyle toplam dört şiirinde redif olarak vefa'yı seçmiştir. Ayrıca nesir olarak yazdığı Âyine-i Devlet adlı eserinde sebat başlığı altında da yine vefayı vurgulamıştır. Onun genellikle âşık-sevgili, dostlukarkadaşlık ve sadâkat bağlamında ele aldı̆̆ı bu kavram, aslında devlet idaresinde memurların azim, göreve bağlllık ve sadâkatini vurgular mahiyettedir.

Şair vefa kavramını genelde olumsuz olarak ele almış ve bu dünyada asla vefanın bulunmadığını Kafdağı, Anka ve Hüma mazmunlarıyla dile getirmiştir. Ayrıca vefa beklentisiyle sürekli ısrar eden âşığın sevgiliye keder verdiğini dile getirerek aslında makam, mevki, para ve ihtiras peşinde koşanların bütün bu yaptıklarıyla devlet otoritesine (padişaha) zarar verdiğini ima etmiştir.

Sonuç olarak Mahmud Nedim Paşa; klasik şiirin imkânlarından yararlanarak siyasî ve sosyal hayatta yaşadığı olumsuzlukları işaret eden şiirler kaleme almış ve bu şiirlerde vurguladığı vefa kavramıyla da bize kederli gönlüne vefalı bir dost aradığı izlenimi vermiştir.

\section{Kaynakça}

Ak, C. (1987). Muhibbî Divanı. Kültür ve Turizm Bakanlığı Yayınları:712, Ankara.

Akdoğan, Y. Ahmedî Dîvân, Kültür ve Turizm Bakanlı̆̆ e-kitap, http://ekitap.kulturturizm. gov.tr/Eklenti/10591,ahmedidivaniyasarakdoganpdf. Erişim Tarihi: 14.10.2019

Akyıldız, A. (2003). Mahmud Nedim Paşa TDV İslam Ansiklopedisi, C. 23, s. 374-376 İstanbul.

Aypay, A. İ. (1992). Nahifi Süleyman Efendi (Hayat,, Eserleri, Edebî Kişiliği ve Divanı’nın Tenkitli Metni). Selçuk Üniversitesi Sosyal Bilimler Enstitüsü, Yayımlanmamış Doktora Tezi.

Çavuşoğlu, M. (1977). Yahya Bey Divan (Tenkidli Basım), İstanbul: İstanbul Üniversitesi Edebiyat Fakültesi.

Çeçen, H. (1996). Fıtnat Hanım Hayatı, Sanatı ve Divanı (İnceleme-Metin). İnönü Üniversitesi Sosyal Bilimler Enstitüsü, Yayımlanmamış Doktora Tezi.

Devellioğlu, F. (2009). Osmanhca-Türkçe Ansiklopedik Lûgat. Ankara: Aydın Kitabevi.

Doğan, M. N. (2010). Fuzûlî Leylâ ve Mecnûn. İstanbul: Yelkenli.

İnal, İ. M. K.. (1941). Son Asır Türk Şairleri, Cüz: 11, İstanbul: Maarif. 
İnal, İ. M. K. (1982). Son Sadrazamlar, Cilt I, 3. Baskı, İstanbul: Dergâh.

İpekten, H.; İsen, M. vd. (1988). Tezkirelere Göre Divan Edebiyat İsimler Sözlüğü, Kültür ve Turizm Bakanlığ, Ankara.

Kaya, G. (2015). Bürokratik Nüfûza Karşı Monarşik Egemenliği Yeniden Kurgulamak Üzerine Bir Girişim: Mahmud Nedim Paşa'nın Görüşlerinde Ahlak ve Devlet İdaresi. OTAM, 38 Güz 2015 S.55-94.

Küçük, S. Baki Divanı. Kültür ve Turizm Bakanlığı e-kitap, http://ekitap.kulturturizm. gov.tr/Eklenti/10596.bakidivanisabahattin.kucukpdf. Erişim Tarihi: 14.10.2019

Kürkçüoğlu, M. A. (2003). Mahmûd Nedim Paşa Divanı İnceleme, Transkripsiyonlu Metin, Sözlük. Sakarya Üniversitesi Sosyal Bilimler Enstitüsü, Yayımlanmamış Yüksek Lisans Tezi.

Naci, Muallim. (1995). Lugat-ı Naci, İstanbul: Çağrı.

Pakalın, M. Z. (2016). Mahmud Nedim Paşa. Ankara: Divan Kitap.

Pala, İ. (1989). Ansiklopedik Divan Şiiri Sözlüğü. Ankara: Akçă̆.

Polat, M. (2003). Mahmud Nedim Paşa. Sakarya Üniversitesi Sosyal Bilimler Enstitüsü, Yayımlanmamış Yüksek Lisans Tezi.

Rıfat, Ahmet. (t.siz). Tasvîr-i Ahlâk-Ahlak Sözlüğü. Haz. Hüseyin Algül, Tercüman 1001 Temel Eser.

Sadıkoğlu, S. (2013). Mahmud Nedim Paşa'nın Bürokraside Gerçekleştirdiği Büyük Tenkihat. Marmara Üniversitesi Türkiyat Araştırmaları Enstitüsü, Yayımlanmamış Yüksek Lisans Tezi.

Sâmî, Şemseddin. (2015). Kâmûs-ı Türkî (Latin Harfleriyle). Haz. Raşit Gündoğdu-Niyazi AdıgüzelEbul Faruk Önal, İstanbul: İdeal Kültür.

Tulum, M.; Tanyeri, M. A. (1977). Nev^̂̀ Divan (Tenkidli Basım). İstanbul: İstanbul Üniversitesi Edebiyat Fakültesi.

Uludă̆, S. (1995). Tasavvuf Terimler Sözlüğü. İstanbul: Marifet.

Yazar, İ. Kân̂̂ Dîvânı, Kültür ve Turizm Bakanlığı e-kitap, http://ekitap.kulturturizm. gov.tr/Eklenti/55833.3-kani-divani.pdf. Erişim Tarihi:14.10.2019

http://www.kuranikerim.com/melmalili/bakara.htm

http://www.sozluk.adalet.gov.tr/Vefa\%2ohakk\%c4\%b1 Erişim Tarihi: 16.11.2019.

http://www.turkedebiyatiisimlersozlugu.com/index.php?sayfa=arama_sonuc\&detayli_arama= Erişim Tarihi:07.12.2019 